\title{
Performance Mechanized Set Tractor-Planter of Sugarcane Planting in Two Operation Shifts
}

\author{
Murilo Aparecido Voltarelli ${ }^{1}$, Rouverson Pereira da Silva ${ }^{1}$, Vicente Filho Alves Silva ${ }^{1}$, Fábio Alexandre \\ Cavichioli $^{1} \&$ Ariel Muncio Compagnon ${ }^{1}$ \\ ${ }^{1}$ UNESP - Univ Estadual Paulista, Campus de Jaboticabal, SP, Brazil \\ Correspondence: Murilo Aparecido Voltarelli, Univ Estadual Paulista, Department of Agricultural Engineering, \\ Campus de Jaboticabal, Jaboticabal, SP, Brazil. Tel: 55-16-3209-2637. E-mail: murilo_voltarelli@hotmail.com
}

\author{
Received: July 23, 2013 Accepted: September 3, 2013 Online Published: October 15, 2013 \\ doi:10.5539/jas.v5n11p54 URL: http://dx.doi.org/10.5539/jas.v5n11p54
}

\begin{abstract}
The studies on the operational performance of sugarcane machinery, in particular the mechanized planting system, are still incipient in Brazil, requiring greater efforts to increase the quality of agricultural operation. In this context, this study aimed to evaluate the operational performance of sugarcane mechanized planting in two operation shifts. The mechanized planting was conducted in the municipality area of Monte Alto - São Paulo (SP), Brazil. The statistical design was completely randomized, totaling 80 sampling points, from which 40 points for daytime operation and 40 points for nighttime operation. The variables evaluated were: displacement speed, engine rpm, engine oil pressure, engine water temperature, effective field capacity, and hourly and effective fuel consumption. The coefficient of variation is greater for the alignment of the tractor at night shift, while the coefficients of skewness and kurtosis are higher during day shift. Displacement speed, engine rpm, engine oil pressure, hourly and effective fuel consumption, and effective field capacity showed no influence over the shift operation.
\end{abstract}

Keywords: Saccharum spp., agricultural machinery, mechanization, autopilot

\section{Introduction}

The studies on performance of sugarcane mechanized operations, in day and night shifts, are still scarce in Brazil especially for the operation of mechanized planting, which is one of the most important stages in the cycle of this culture, because if the relation machine-soil-plant-atmosphere (Håkansson, 2005) is not in equilibrium, sugarcane longevity and productivity will be compromised.

The operation performance of sugarcane mechanized planting may be affected, primarily, by factors related to the machine and the mechanized set as: the engine rpm (power demanded by the operation), engine oil pressure (imposed by the oil displacement pump, that aims lubrication of the internal parts of the engine), engine water temperature (is high when the thermostatic valve and other constituents of the system have a problem), tractor alignment error (it can cause loss of accuracy in operation), hourly and effective fuel consumption (displacement speed and engine rpm, and influenced by effective field capacity, respectively) and the effective field capacity of the mechanized set (the higher the better may be the performance of the operation).

If at least one of the factors cited above, which work together, is in poor working conditions, depending on the conditions imposed by the soil and land slope (Garside et al., 2009a), it will be very difficult to attend the prerequisites stipulated by the producing unit, and the operation will not achieve the desired quality, thus compromising the whole farm planning, so the settings and both the preventive and corrective maintenance must be performed frequently (Garside et al., 2009b).

Thus, associating the small variations of spacing adjustment between the furrow ploughs of the planter and the alignment error at the time of the sugarcane mechanized planting, if these factors did not suffer an adequate regulation, it will potentially occur loss of the desired accuracy for the operation, causing possible alignment errors, which can exceed the acceptable tolerance limits by the producing units, and, thus, the subsequent operations as well as the input applications, mechanized harvesting and other machinery traffic in the area will be harmed (Garside et al., 2009a).

Moreover, Shockley et al. (2011) said that the autopilot, by the alignment error verified in onboard computer in the operator's cab, reduces overlaps and gaps in application, enabling greater accuracy in the operation. 
In this context, assuming that the operation performance of sugarcane mechanized planting is influenced depending on the operation shifts, this study aimed to evaluate the behavior of variables operating performance of the sugarcane tractor-planter set in operational day and night shifts.

\section{Methods}

\subsection{Plant Materials and Experimental Conditions}

The experiment was conducted in the municipality of Monte Alto - SP, Brazil, near the geodetic coordinates: Latitude $21^{\circ} 16^{\prime} 42^{\prime \prime} \mathrm{S}$ and Longitude $48^{\circ} 24^{\prime} 21^{\prime \prime} \mathrm{O}$ e elevation of 620 meters, an average slope of $6 \%$ and Aw climate according to Köeppen classification. The geo-referencing of the area was made with the assistance of a GNSS receiver, Trimble brand, model R6 (centi millimetric positional accuracy) and the coordinates were registered in the UTM (Universal Transverse Mercartor) Cartesian system.

The variety used in the operation of mechanized planting of sugarcane was the RB83-5453, developed by Brazilian Universities Network (RIDESA), possessing characteristics such as drought tolerance, early maturity and good productivity. The planting density was $15 \mathrm{gems} \mathrm{m}^{-1}$, featuring an average billets consumption around $23 \mathrm{Mg} \mathrm{ha}^{-1}$ for the two shift operation.

\subsection{Soil Conditions}

Prior to the sugarcane mechanized planting, the area was cultivated with soybean and after harvesting, the sugarcane mechanized planting operation was carried out. The soil periodical preparation (used a harrowing average disc and another leveling) was done before the soybean planting, after sub-soiling at a depth of $0.50 \mathrm{~m}$. The characterization of the amount of straw left by the soybean crop was obtained by collecting ten random points in the area, resulting in $938.03 \mathrm{~kg} \mathrm{ha}^{-1}$ of dry mass. Ten samples were taken from the soil $(0-0.20 \mathrm{~m})$ to determine the texture class, giving as result $78 \%$ sand, $6 \%$ silt and $16 \%$ clay and were; therefore, classified as medium texture according to the methodology proposed by Jones (2001). The adjustment of the furrow depth was carried out at $0.30 \mathrm{~m}$, as stipulated by the company.

To detect the location, where it was compacted soil was used penetrometer PNT Titan Automation Industrial Ltda, built according to standard ASAE S313.3 (ASABE, 2006). It had a storage capacity of 2048 samples geo-referenced, cell load of $1500 \mathrm{~N}$ for measuring the force of penetration resistance, electric motor current continues voltage with $12 \mathrm{~V}$ and $24 \mathrm{~W}$ of power supplied by the electrical system of the quad bike, which triggers a system and reduction helical thread, to which the load cell is attached to this rod. The equipment had a capacitive-inductive sensor for measuring the depth and acquires data up to $0.55 \mathrm{~m}$ deep with penetration speed of $0.03 \mathrm{~m} \mathrm{~s}^{-1}$ and acquisition frequency of $3 \mathrm{~Hz}$. The layer of higher resistance to this soil penetration was in a depth of 0.10 to $0.20 \mathrm{~m}(3.14 \mathrm{MPa})$. The characterization of the soil water content was realized by collecting 160 samples, 80 for each period of operation in layers of $0-0.15$ and $0.15-0.30 \mathrm{~m}$ according to the methodology recommended by Buol et al. (2011). During daytime and nighttime, soil water content in the layer $0-0.15 \mathrm{~m}$ was 7.0 and $8.5 \%$ and in the depth $0.15-0.30 \mathrm{~m}$ was 6.5 and $9.0 \%$, respectively.

\subsection{Tractor and Planter Characteristics}

The sugarcane mechanized planting was carried out in March of 2012 by a planter set, composed of a 4 x 2 FWA tractor, with engine power of $136.0 \mathrm{~kW}$ at $2200 \mathrm{rpm}, 6$ cylinders, with 17:1 compression ratio, front 600/65R 28 and rear 710/70R38 wheeling, both R1W, and a chopped sugarcane planter of 2 row with capacity of $6 \mathrm{Mg}$ of billets for planting, fertilizer box of $1.300 \mathrm{~kg}$, having a width of 3.60 meters, wheeling 600/50 22.5, with shanks spaced $1.50 \mathrm{~m}$. The tractor operated with the gauge adjusted to $2.70 \mathrm{~m}$ and in a working march $1 \mathrm{~B}$. During the planting operation there was an application of $400 \mathrm{~kg} \mathrm{ha}^{-1}$ of fertilizer and $100 \mathrm{~L} \mathrm{ha}^{-1}$ spray of the insecticide imidacloprid. The set was equipped with an automatic steering hydraulic system of the planting alignment (automatic pilot), composed of onboard computer model Fmx ${ }^{\circledR}$, GPS receiver model AgGPS (both Trimble), and other accessories. This system uses the kinematic positioning method for real-time (Real Time Kinematic - RTK) with communication rover-based via radio signal reaching horizontal positioning quality around $0.025 \mathrm{~m}$.

\subsection{Tractor Performance and Mechanized Set}

The performance evaluations of the planter set consisted of: displacement speed, engine rotation, engine oil pressure, engine water temperature, and the hourly fuel consumption being all variables collected through the front column monitor (Command Center ${ }^{\mathrm{TM}}$ ) installed inside the tractor's cabin, these variables being monitored in real time by means of specific sensors allocated to specific points of the engine. The alignment error of the tractor was collected in real time in onboard computer $\mathrm{Fmx}^{\circledR}$ Integrated Display. The field effective capacity was calculated according to the methodology described by Liljedahl et al. (1989) and the effective consumption was calculated according to the methodology described by Srivastava et al. (1993). 


\subsection{Treatments}

The experimental design was completely randomized with two treatments according to the afternoon shift operation delimited from 3:00 to 11:00 pm. This time was chosen to allow assessment of the operation of mechanized planting of the sugarcane during the daytime (3:30 to 05:30 pm) and night (07:30 to 09:30 pm) without need to change operator; thus, providing better control of the experiment. For this experiment, two mesh samples were established with pre-set 40 replications, with spacing of $50 \times 1.5 \mathrm{~m}$ apart, with 40 replications for evaluations during the day shift (1-40) and 40 replications during the night $(41-80)$.

\subsection{Statistical Analysis}

The general demonstration of data behavior was made from the descriptive statistics, calculating measures of central tendency (mean and median), measures of dispersion (range, standard deviation and coefficient of variation) and skewness measures and kurtosis. The verification of data normality was performed by Anderson-Darling test, being a measure of proximity of the points and the line estimated in the probability giving greater stiffness to the analysis (Acock, 2008), and when asymmetric it was realized the transformation of the data set using the best adjustment for each variable (BOX COX transformation), and the best adjustment equation was designated by the computer program Minitab $16^{\circledR}$.

The box plot is composed of some descriptive parameters, such as the median (Q2), the lower (Q1) and the upper (Q3) quartile, interquartile range $(\mathrm{IQR}=\mathrm{Q} 3-\mathrm{Q} 1)$, the minimum and maximum values and by the outliers $($ denoted by $*$ ) being particularly suited for the detection of the outliers and for comparing two or more data sets corresponding to a variable, as well as presenting an overview of the behavior of the dispersion of the data, and is commonly used for better interpretation of statistical results.

The analysis of variance (ANOVA) single factor was carried out by applying the F test, with significance level of $1 \%$ to check whether or not there are significant differences between the means of the variables analyzed. When appropriate, was applied the Tukey test at 1 and $5 \%$ probability to compare the means.

\section{Results and discussion}

\subsection{Analysis of Descriptive Statistics}

The variables hourly and effective fuel consumption for day and night operation shifts (Table 1) can be described by the function normal probability density according to the Anderson-Darling test.

On the other hand the variables speed, engine rpm and effective field capacity for the day shift and engine rpm and engine oil pressure for the night shift showed high coefficients of skewness (negative) and kurtosis (positive), featuring more elongated distribution curves to the left and greater thinning, respectively, and this one may be called as leptokurtic, in relation to normal curve, despite the low coefficient of variation and standard deviation values. Bai and $\mathrm{Ng}$ (2005) reported an association between the coefficients of skewness and kurtosis to predict the behavior of the data being monitored over time, and can infer the variability in a given sample and parameters. According to Mudholkar and Natarajan (2002), the analysis of data set distribution and variability is interesting to assess the parameters.

The tractor alignment error for the day shift, and the speed, the tractor alignment error and the effective field capacity for the night shift showed high coefficients of skewness and kurtosis, both positive, showing the concentration of points above average and a flattened distribution curve in relation to normal distribution curve, respectively. In particular, the variable tractor alignment error for the two operation shifts showed high coefficient of variation, standard deviation and amplitude.

The variable engine water temperature for both operation shifts had a lower mean than the median, characterizing elongated distribution curve to the left, and it can be verified by the high negative coefficient of skewness. Also for the variable engine oil pressure during the day operation shift, it can be seen a platicurtic curve in relation to the normal. The study of parameters statistics descriptive serve to give an overview of the behavior of the data in a given distribution Léon et al. (2005) and also can predict what is occurring in certain processes (Kim \& White, 2004). 
Table 1. Descriptive statistics for the variables of performance of sugarcane mechanized planting in relation to the operation shifts

\begin{tabular}{|c|c|c|c|c|c|c|c|}
\hline \multicolumn{8}{|c|}{ Day shift } \\
\hline Variable & $\mathbf{R}$ & $\sigma$ & $\mathbf{M}$ & Cs & $\mathbf{C k}$ & $\mathbf{C V}$ & $\overline{A D}$ \\
\hline Speed $\left(\mathrm{km} \mathrm{h}^{-1}\right)$ & 0.30 & 0.06 & 5.40 & -1.45 & 3.89 & 1.20 & A \\
\hline Engine rpm (rpm) & 90.00 & 19.01 & 2,170 & -1.84 & 4.21 & 0.88 & A \\
\hline Engine oil pressure $(\mathrm{kPa})$ & 40.00 & 11.54 & 370 & 0.22 & -1.00 & 3.08 & A \\
\hline Engine water temperature $\left({ }^{\circ} \mathrm{C}\right)$ & 8.00 & 2.49 & 83 & -0.53 & -0.98 & 3.03 & A \\
\hline Tractor alignment error $(\mathrm{cm})$ & 61.00 & 9.61 & 3.00 & 5.66 & 34.10 & 197 & A \\
\hline Hourly fuel consumption $\left(\mathrm{L} \mathrm{h}^{-1}\right)$ & 20.10 & 3.89 & 26.70 & 1.18 & 3.39 & 14.49 & $\mathrm{~N}$ \\
\hline Effective fuel consumption $\left(\mathrm{L} \mathrm{ha}^{-1}\right)$ & 0.09 & 3.57 & 23.67 & 1.18 & 3.14 & 14.92 & $\mathrm{~N}$ \\
\hline Effective field capacity $\left(\mathrm{ha}^{-1}\right.$ ) & 0.09 & 0.01 & 1.62 & -1.45 & 3.89 & 1.20 & A \\
\hline \multicolumn{8}{|c|}{ Night shift } \\
\hline Speed $\left(\mathrm{km} \mathrm{h}^{-1}\right)$ & 0.60 & 0.10 & 5.30 & 4.22 & 22.41 & 1.89 & $\mathrm{~A}$ \\
\hline Engine rpm (rpm) & 80.00 & 16.80 & 2,160 & -0.84 & 1.07 & 0.78 & A \\
\hline Engine oil pressure $(\mathrm{kPa})$ & 84.00 & 14.85 & 380 & -2.44 & 9.87 & 3.98 & A \\
\hline Engine water temperature $\left({ }^{\circ} \mathrm{C}\right)$ & 5.00 & 1.55 & 81 & -0.48 & -0.86 & 1.91 & A \\
\hline Tractor alignment error $(\mathrm{cm})$ & 79.96 & 14.28 & 2.00 & 5.38 & 29.26 & 297 & A \\
\hline Hourly fuel consumption $\left(\mathrm{L} \mathrm{h}^{-1}\right)$ & 21.60 & 3.65 & 25.25 & -0.66 & 3.45 & 14.35 & $\mathrm{~N}$ \\
\hline Effective fuel consumption $\left(\mathrm{L} \mathrm{ha}^{-1}\right)$ & 0.18 & 2.59 & 22.41 & -0.58 & 3.49 & 14.50 & $\mathrm{~N}$ \\
\hline Effective field capacity $\left(\mathrm{ha}^{-1}\right)$ & 0.02 & 0.02 & 1.40 & 4.22 & 22.41 & 1.89 & A \\
\hline
\end{tabular}

$\mathrm{R}$ - Range; $\sigma$-Standard deviation; M - Median; Cs - Coefficient of skewness; Ck - Coefficient of kurtosis; CV (\%) - Coefficient of variation; $\mathrm{AD}$ - Normality test of Anderson-Darling (N: normal distribution; A: asymmetric distribution).

\subsection{Analysis of Variance}

\subsubsection{Variables of the Machine-Tractor}

For most variables, in both treatments, it was observed the occurrence of outliers, which can be visualized in the box plots. These results were maintained in all statistical analyzes, since these outliers are part of the process and may help to identify the occurrence of special causes, inherent to it.

There was no difference among the assessed treatments, which shows that the mean displacement speed (Figure 1) was uniform during the day and the night operation shifts, a fact that can be stated due to the slight variation in the interquartile amplitude, indicating that the values are grouped regardless of the outliers detected, which may indicate greater soil resistance by the decreasing of the speed and the increasing of the speed by land slope to the day and night shift, respectively. 


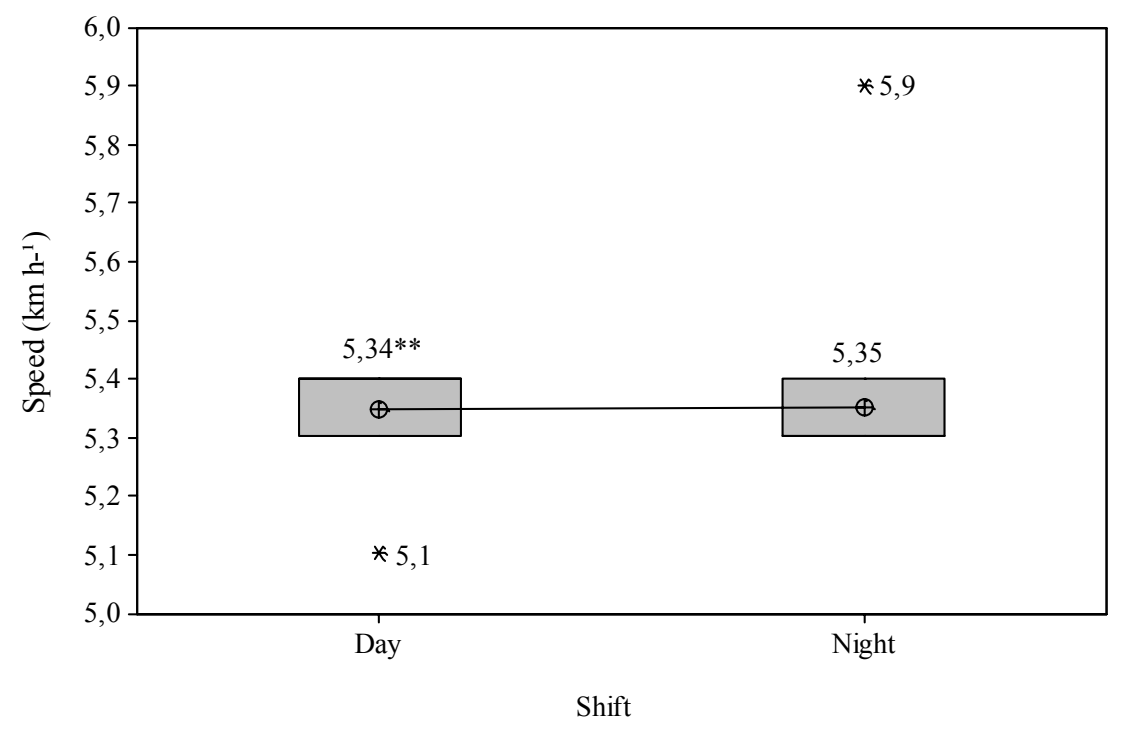

Figure 1. Mean speed in the operation of sugarcane mechanized planting in two operation shifts. ${ }^{* *}$ Means followed by the absence of letters indicate no significance by $\mathrm{F}$ test at $(\mathrm{P} \leq 0.01)$ probability

This aspect in relation to sugarcane mechanized planting becomes interesting because it can be used as an indicator that the distribution of billets may have been uniform attending the requisite standard by the producing unit, in the operation shifts, once that the adjustment of the billets distributor mat is associated to the displacement speed of the machine.

The displacement speed during the day and night operation shifts is within the recommended limits ( 5 to $8 \mathrm{~km} \mathrm{~h}^{-1}$ ) in accordance with the technical manual of the planter (TMA, 2013), but the speed reached in the operation is close to the minimum speed recommended, which might decrease the effectiveness of the operation, because, as reported by Ivancan et al. (2004), the displacement speed influences the implementation of cultures and the performance of the operation, since the speed, when in excess, impairs the final productivity and do not allow the proper distribution of the amount of gems or seeds $\mathrm{m}^{-1}$, whereas low speed reduces the operational capacity of the mechanized set. Moreover, Vishwanathan et al. (2005) and Kicher et al. (2007) reported that the speed of displacement of mechanized set collected in real-time using sensors that are monitored and controlled by computer have small margins of error and can portray the real condition of field.

There was no difference between treatments for variable engine rpm (Figure 2) despite the low values of the standard deviation and coefficient of variation, which may indicate small values of dispersion, although the interquartile amplitude possess the same magnitude in both operation shifts and the concentration of dots for day shift is below the mean, and this may be observed by the distribution tail. 


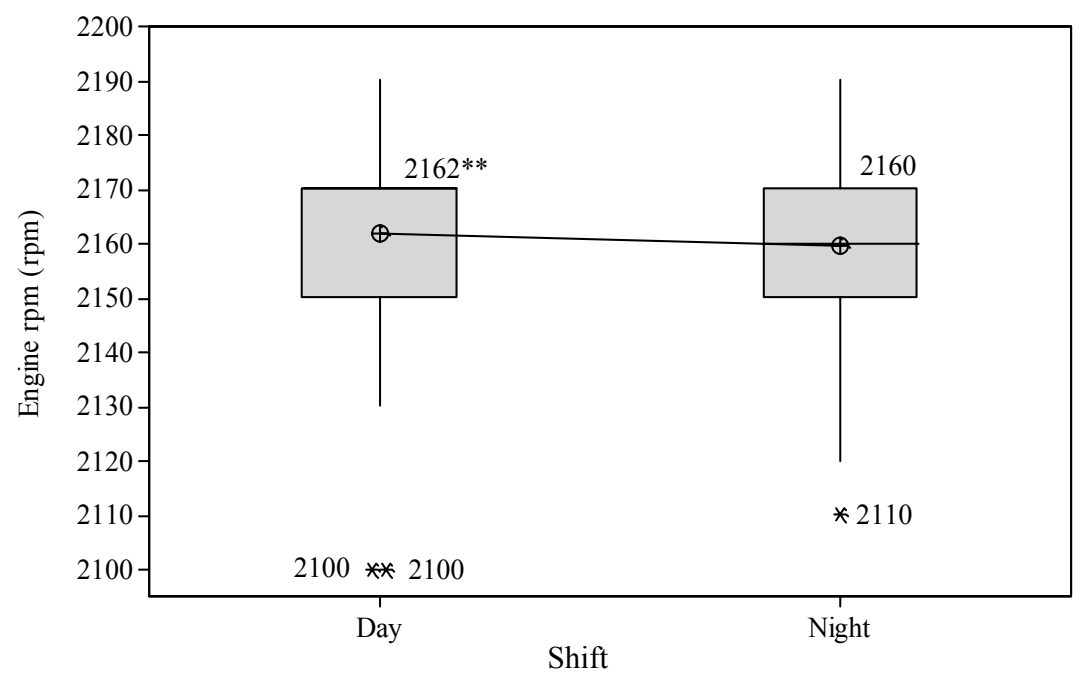

Figure 2. Engine rpm in the operation of sugarcane mechanized planting in two operation shifts. ${ }^{* *}$ Means followed by the absence of letters indicate no significance by $\mathrm{F}$ test at $(\mathrm{P} \leq 0.01)$ probability

The engine rpm being equal for the two operation shifts, may be an indication that the power demanded by the tractor in this situation was also constant in most part of the operation and that the conditions of soil, topography and soil water content, and the operation dimensioning are favorable to the performance of mechanized set during the workday.

The engine rpm, to achieve the maximum effective power, is $2.200 \mathrm{rpm}$ according to the technical manual of the machine (John Deere, 2008), and this may indicate that the power of the machine was being used near the maximum condition, which reflects in the upper limit of the angular speed of the engine use range, i.e., the torque in this situation is reduced. Furthermore, the hourly fuel consumption is in the highest range, indicating that the tractor was in an operational condition in which the specific consumption was above the minimum point. This behavior was expected, since the tractor worked near the maximum rotation power, which leads to a higher hourly consumption and low torque.

It can also be observed that, for the day shift a few points, on which there was a decrease of engine rpm demonstrated by outliers, may show greater soil resistance on this sampling site, causing increased demand of tractor power, and this hypothesis may be confirmed when associated with low-speed point.

For the engine oil pressure, there was no influence of the day or night operation shifts (Figure 3), although the interquartile amplitude is greater during the day, indicating greater variability of values. It was also observed that, for the day operation shift, the mean is higher than the median, which features a more elongated distribution to the right with concentration of points below average, a fact that can be verified by the distribution tails, and this behavior is opposite to that observed for the night shift. 


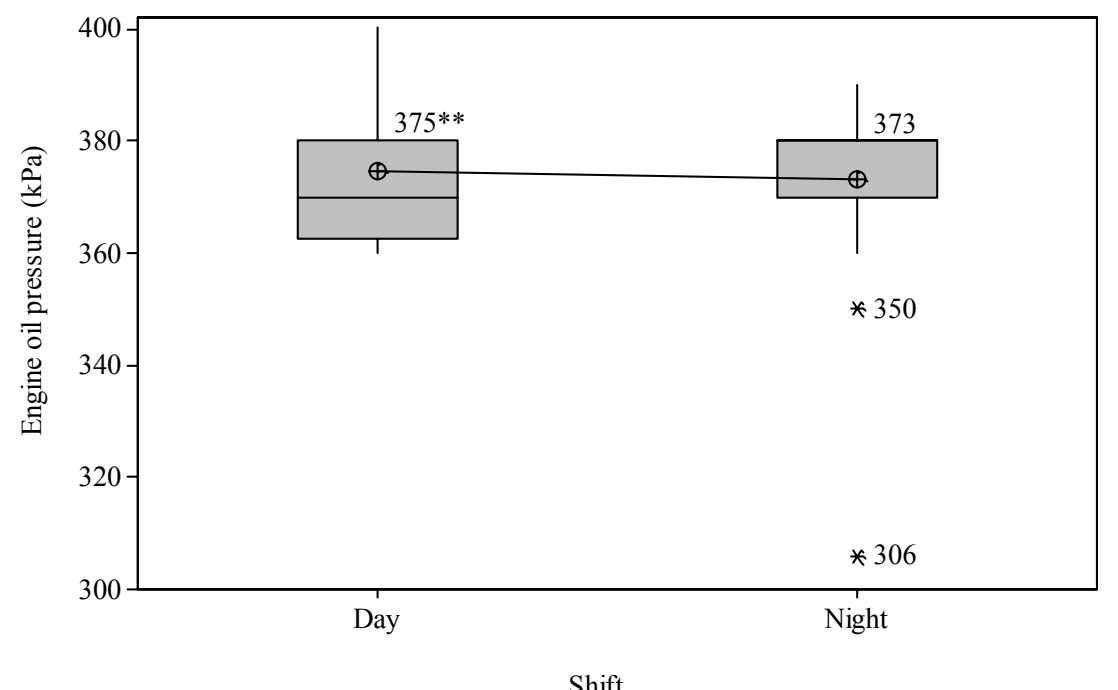

Figure 3. Engine oil pressure in the operation of sugarcane mechanized planting in two operation shifts

** Means followed by the absence of letters indicate no significance by $\mathrm{F}$ test at $(\mathrm{P} \leq 0,01)$ probability

The non-influence of operation shifts, in the values of the means, can be explained by the correct functioning of the displacement pump in the moment of the distribution of oil to the engine. This type of pump is operated releasing a larger amount of oil than is necessary to lubricate the engine and its excess returns to the sump through the action of the pressure regulating valve. Pripps (2004) reported that the rotation of a diesel engine operating between 1.800 and $2.100 \mathrm{rpm}$, the pressure has to be around 345 to $483 \mathrm{kPa}$ for the correct lubrication of the moving parts of the engine, as happens in the present study, the rpm and the engine oil pressure are within the stated range, this reinforces the correct functioning of the injection pump. Karra and Fernando (2005) reported that the monitoring of oil pressure as well as temperature are essential parameters for quality lubricant which can directly affect its viscosity.

For the night shift, the occurrence of outliers, which accused lowest values of engine oil pressure, may be explained by several reasons, among them: longer opening time of the pressure regulator valve, preventing the pump to direct the oil flow to the engine, i.e., most part of the oil returns to the sump; low oil level in the sump; return pipe clogged due to excessive contamination; air intake in the system or even the leaking of the injector nozzle, may decrease the viscosity of the oil.

There were differences among the assessed treatments for the variable engine water temperature when was compared the day shift with the night shift, and the day shift had the highest temperature (Figure 4). It was also observed that despite the day shift had higher mean engine water temperature, the concentration of points, of day and night shifts, is displaced above the mean, as evidenced by the distribution tails and by the coefficients of skewness, representing the proper functioning of the engine cooling system.

This fact can be explained by the interquartile amplitude, and this is greater in the day shift due to the greater variation of the engine water temperature, there may be interference of the ambient temperature between the operation shifts due to the exposure to sunlight. Furthermore, during the night there is no sunlight, which may have reduced the interquartile range, causing a relatively low variability of the data set, reflecting in the concentration values around the mean despite the skewness demonstrated by Anderson-Darling test. This explanation may be confirmed by the standard deviation and coefficient of variation of the night operation, which was lower when compared to daytime (Bai, 2003).

Pripps (2004) reported that the normal range of the engine water temperature vary between 71 and $82{ }^{\circ} \mathrm{C}$. Above this last value, the cooling system of the machine has to perform the opening of the thermostatic valve for the occurrence of water passage to the internal engine parts, i.e., the engine cooling occurs to prevent overheating and possible damage in its operation due to the heat generated. 


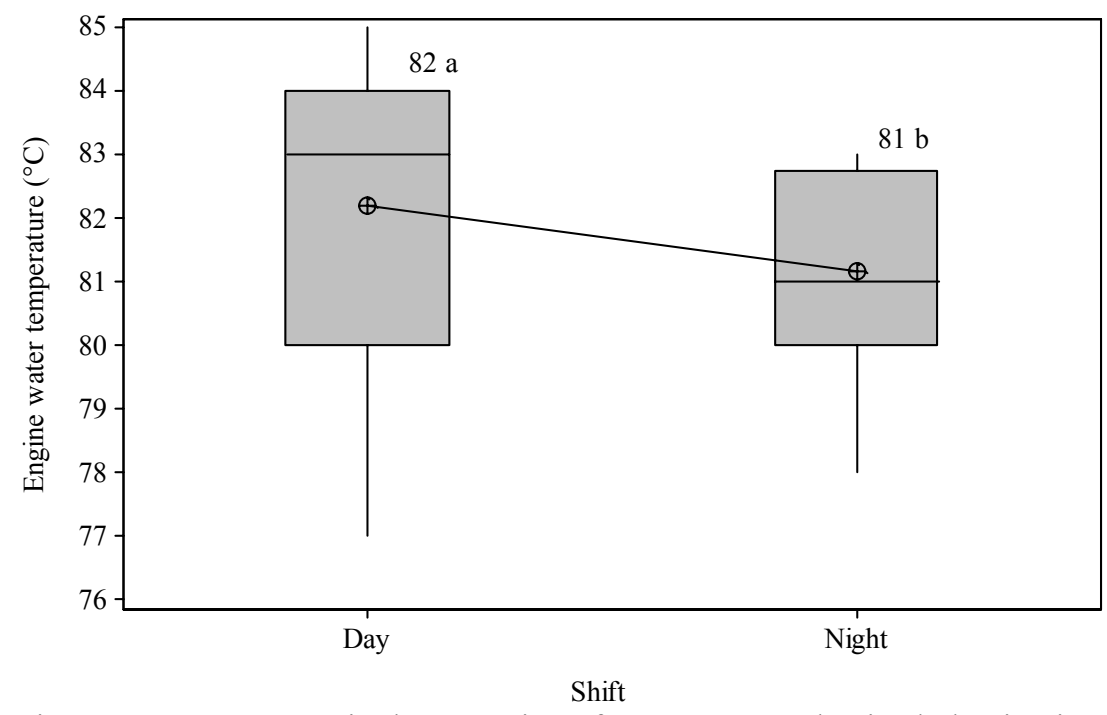

Figure 4. Engine water temperature in the operation of sugarcane mechanized planting in two operation shifts. **Means followed by the present of letters indicate significance by Tukey test at $(\mathrm{P} \leq 0,01$ and 0,05$)$

probability

For the variable tractor alignment error, there was difference between treatments depending on the operation shift (Figure 5), with the longest mean error occurred during the daytime, also having high dispersion of data, which may be confirmed by high values of standard deviations and coefficients of variation.

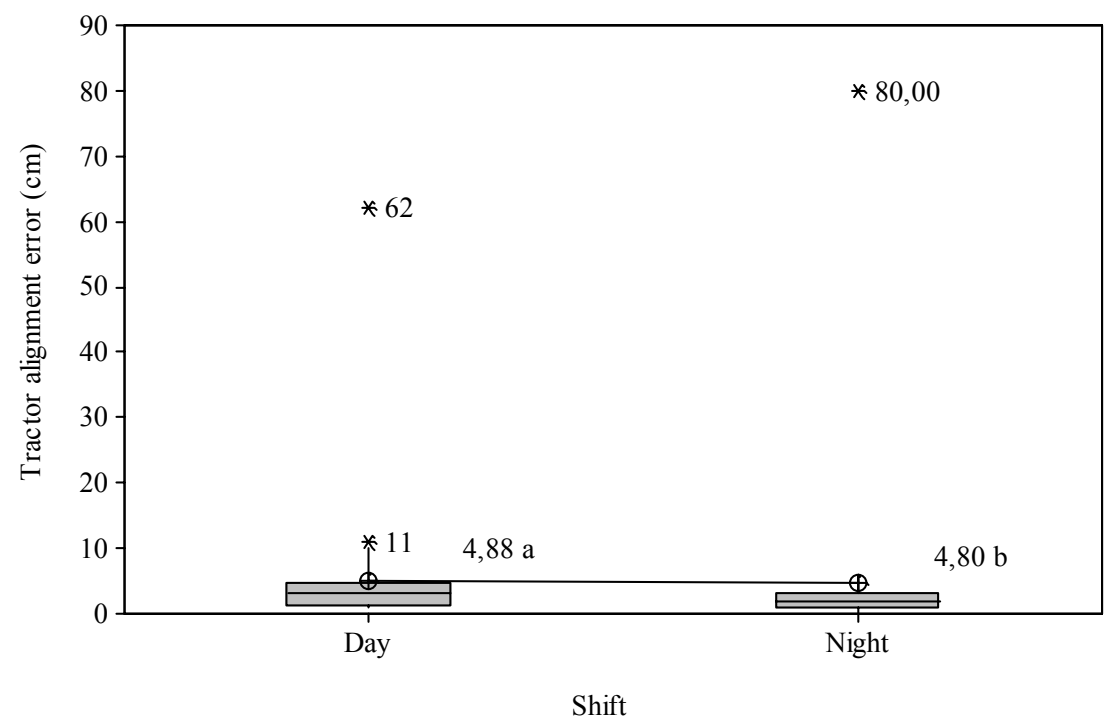

Figure 5. Tractor alignment error in the operation of sugarcane mechanized planting in two operation shifts. Means followed by the present of letters indicate significance by Tukey test at $(P \leq 0,01$ and 0,05$)$ probability

This significant effect may have underestimated the operation during the night, because during the workday there was no loss of signal, i.e., the machine worked 11 points without the accuracy of automatic guidance system, which can result in errors of parallelism and loss of accuracy for the other future operations, as sugarcane mechanized harvesting, so the response of this variable cannot be summarized in only one analysis with mean values. This explanation can also be supported by taking into account the lower interquartile amplitude shown in the night operation, because of the lack of values due to the loss of signal. Baio (2012) suggested that operation quality to be the highest in mechanized sugarcane, using the pilot automatic operation 
of planting, in which the errors are the smallest as possible. On the other hand, the use of autopilot in agricultural operations to decrease the alignment of the operation is always an interesting topic of study by various researchers, which is not always possible to achieve a maximum accuracy and can cause quality loss in future operations at any stage of any crop cycle (Heraud \& Lange, 2009). Another factor that may be taken into consideration is the presence of outliers which are present in both operation shifts, and this is also a factor that generates more variability in the data set and it can be explained by the delay of the signal received by the mobile receiver or by failure of the operator at the time of driving the mechanized set. On the other hand, the use of autopilot in agricultural operations to decrease the alignment of the operation was always a matter of studies by various researchers, which is not always possible to achieve a maximum accuracy provided by the system and when that happens can cause loss quality of future operations at any stage of any crop cycle and when used in the right way and more efficiently can bring significant reductions in costs production according the report done by (Batte \& Ehsani, 2006).

\subsubsection{Performance of Mechanized Set - Tractor-Planter}

There was no difference between day and night operation shifts for the effective field capacity (Figure 6). This fact can be supported by the displacement speed control of the mechanized set by the operator, in both shifts, and this has a direct influence on the calculation of this variable.

The effective field capacity in the operation of mechanized planting of sugarcane, using a tractor of $161 \mathrm{~kW}$ operating at $2.200 \mathrm{rpm}$ in the engine in $2 \mathrm{~B}$ gear with speed of $5.3 \mathrm{~km} \mathrm{~h}^{-1}$ and a DMB planter of chopped sugarcane, PCP 5000 model, was of $1.58 \mathrm{ha} \mathrm{h}^{-1}$ (M. L. C. Rípoli \& T. C. C. Rípoli). The speed used by these authors was similar to the present study, but the tractor used for this operation had the engine power of $136 \mathrm{~kW}$, with planting spacing $1.50 \mathrm{~m}$.

Moreover, studying the sugarcane mechanized planting in India, Kumar and Singh (2012), used a tractor with less power and a sugarcane planter, khalsa brand, P-603 model, of lower mass. The effective field capacity of the machine was approximately $0.38 \mathrm{ha}^{-1}$ with a working speed of 1.8 to $2.5 \mathrm{~km} \mathrm{~h}^{-1}$, a value much lower than the displacement speed of the mechanized set used in this study. On the other hand, Yadav et al. (2004) studied the same sugarcane planter, with the same machinery and displacement speed, in several regions of India, and found a value of effective field capacity from 0.08 to $0.18 \mathrm{ha} \mathrm{h}^{-1}$, and these situations were also lower than the present study.

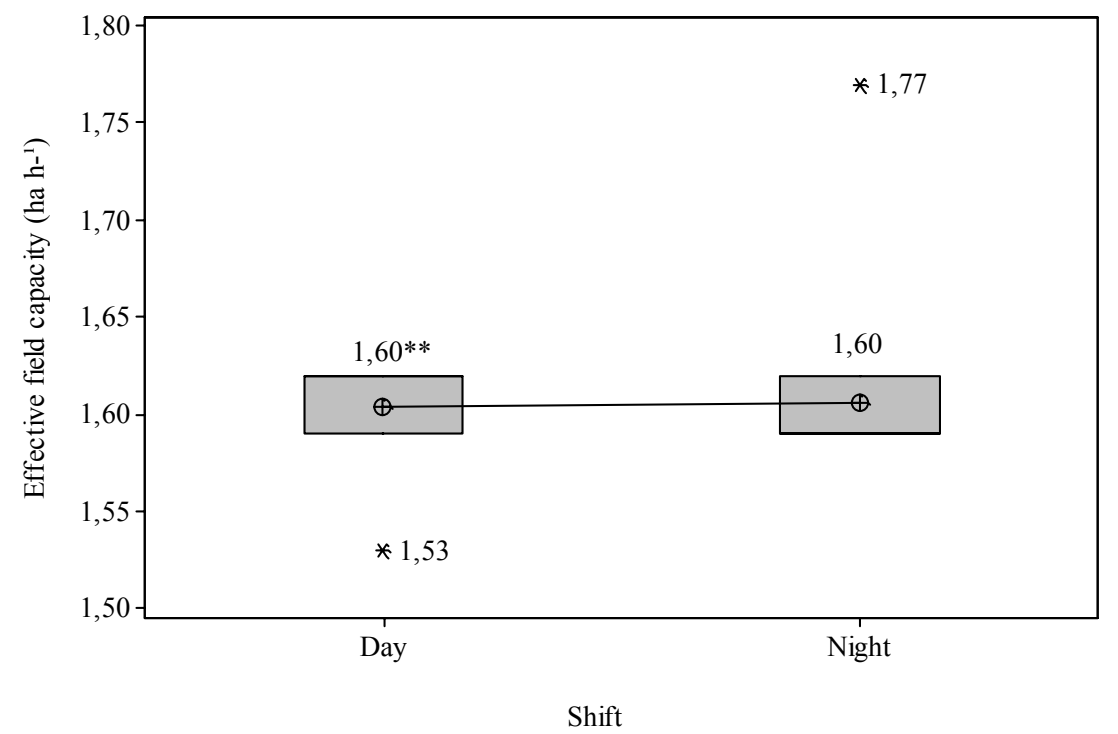

Figure 6. Effective field capacity in the operation of sugarcane mechanized planting in two operation shifts. ${ }^{* *}$ Means followed by the absence of letters indicate no significance by $\mathrm{F}$ test at $(\mathrm{P} \leq 0,01)$ probability

Another fact that can be taken into consideration is that, although the box plots graphics do not show distribution tails, the concentration of points is below and above the mean, for the day and night operation shifts, respectively, 
as can be verified by the coefficients of skewness. The outliers for this variable occurred due to the displacement speed of the mechanized set, in which it suffered decrease and increase in the day and night shifts, respectively.

There was no difference between treatments for the variable hourly fuel consumption (Figure 7), since this variable can be influenced by the displacement speed and the engine rpm and both possessed a similar behavior between work shifts, i.e., they did not differ, and therefore there was no situation in which the energy expenditure could be larger.

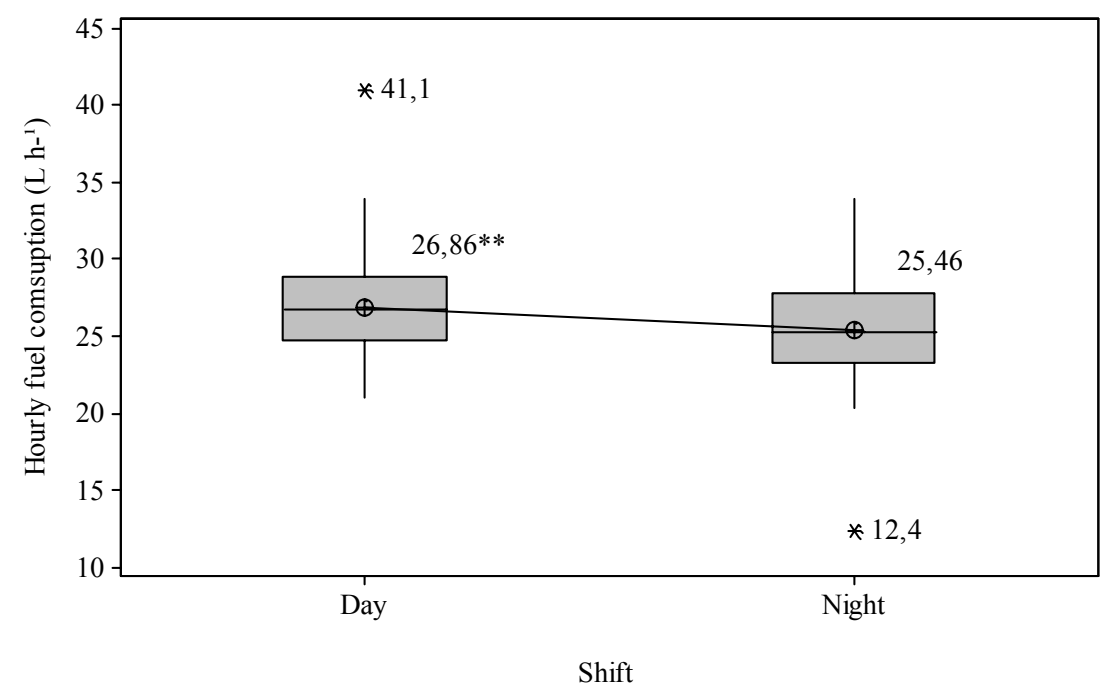

Figure 7. Hourly fuel consumption in the operation of sugarcane mechanized planting in two shifts of operation. ${ }^{* *}$ Means followed by the absence of letters indicate no significance by $\mathrm{F}$ test at $(\mathrm{P} \leq 0,01)$ probability

It must be also noted that the values of hourly fuel consumption are displaced slightly below average for day and night operation shifts, and they can be evidenced by the distribution tails of box plot graphs. It is also highlighted that, for this variable, the minimal presence of outliers occurred by random causes, and may not have directly influenced the operation as a whole.

The hourly fuel consumption in the operation of sugarcane mechanized planting, using a Civemasa billets cutter planter, model PCSA $2 / 2$, being pulled by a tractor of $161 \mathrm{~kW}$ and operating at $2.200 \mathrm{rpm}$, with speed of approximately $5.0 \mathrm{~km} \mathrm{~h}^{-1}$, was $40.24 \mathrm{~L} \mathrm{~h}^{-1}$ according to M. L. C. Rípoli and T. C. C. Rípoli (2010), higher than that obtained in this study, due to the fact the tractor used for this operation have less engine power $(136 \mathrm{~kW})$. It was also observed that, if it is compared the two mechanized plantations, and if it is used a tractor with $136 \mathrm{~kW}$ engine for this operation, as in this study, it can pull the planter of chopped sugarcane with an hourly fuel consumption of approximately $35 \%$ lower than compared to a tractor with $161 \mathrm{~kW}$ of engine power.

The hourly fuel consumption is high when the tractor does work at high rotation of the engine, either a greater or lesser load and / or with greater or lesser power to the motor, as described by Grisso et al. (2004), and this prediction becomes very important, because it might reflect production costs and to infer the classification of tractors designating them for each operation according (Gil-Sierra et al., 2007).

The effective fuel consumption did not differ among treatments (Figure 8). This situation can be explained due to the hourly fuel consumption and the effective field capacity, variables which relate to each other to obtain the values of effective fuel consumption, and they did not differ among themselves during the shifts operation, as the mean values were close and similar, they were not sufficient to reflect in the influence of the effective fuel consumption variable. 


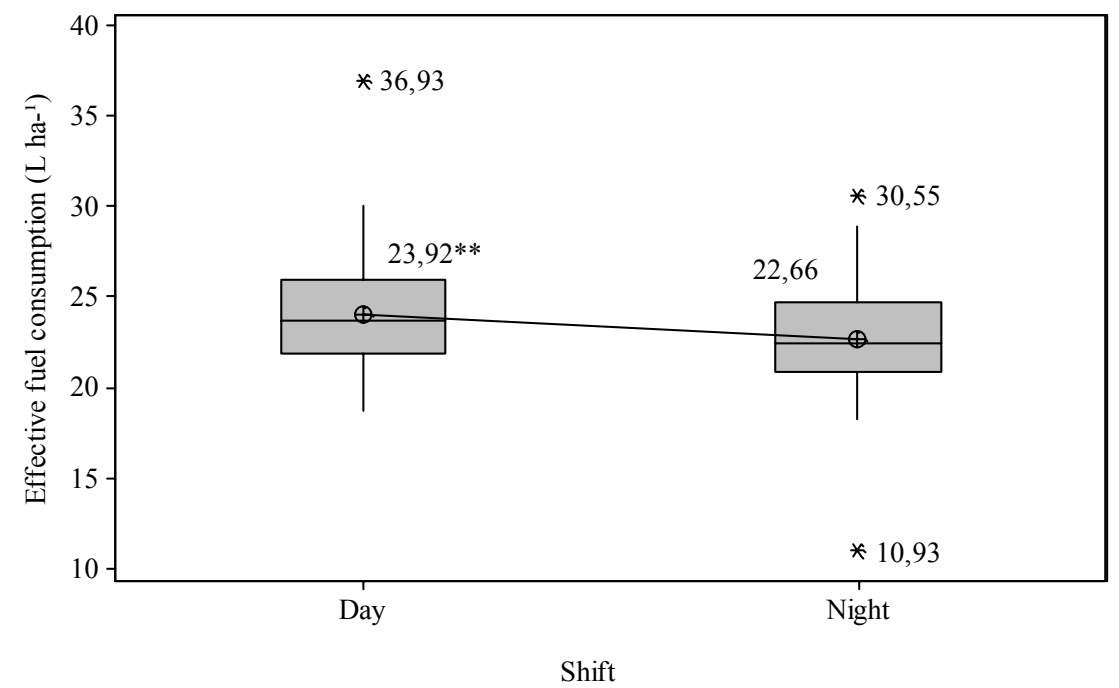

Figure 8. Effective fuel consumption in the operation of sugarcane mechanized planting in two operation shifts. **Means followed by the absence of letters indicate no significance by $\mathrm{F}$ test at $(\mathrm{P} \leq 0,01)$

probability

It can also be observed that the existence of outliers for this variable also occurred due to random causes, and may not be harmful in the behavior of this variable. Another factor that may be taken into account is that, for day and night operation shifts, there was concentration of points slightly below the average, as can be evidenced by the distribution tails of values in the box plot graphics, and that can be proven by the coefficients of skewness, although at night, the mean was trivially larger than the median. M. L. C. Rípoli and T. C. C. Rípoli (2007) found values of effective consumption of fuel for mechanized planting of sugarcane very close to the present work, using tractors with power of $136 \mathrm{~kW}$, and this being essential for the performance evaluation of operation of mechanized planting of sugarcane, because it can reflect the improvement in production costs through a proper management (Yadav et al., 2003).

Kumar and Singh (2012) studied a model of sugarcane planter, khalsa brand, P-603 model, using a tractor with less power and a planter of less mass, operating at a working speed of 1.8 to $2.5 \mathrm{~km} \mathrm{~h}^{-1}$, and they reported that the effective fuel consumption was $22 \mathrm{~L} \mathrm{ha}^{-1}$, a situation close to that found in this study, despite the conditions of the tractors and the machines be different.

\section{Conclusion}

The coefficient of variation is greater for the alignment of the tractor at night shift, while the coefficients of skewness and kurtosis are higher during day shift.

The operational performance of the tractor-planter set is affected by work shifts, and the engine water temperature and the tractor alignment error are higher during the day operation shift.

The displacement speed, engine rpm, engine oil pressure, hourly and effective fuel consumption and effective field capacity have no influence over the operation shifts.

The displacement speed, engine oil pressure, tractor alignment error and effective field capacity have higher variability during the night operation shift.

\section{Acknowledgements}

The authors thank the National Council for Scientific and Technological Development and Coordination of Improvement of Higher Education Personnel, by grants granted to authors.

\section{References}

Acock, A. C. (2008). Descriptive statistics and graphs for one variable. In A. C. Acock (Ed.), A gentle introduction to stata (pp. 83-107). College Station: Stata Corp.

American Society of Agricultural and Biological Engineers. (2006). S313.3 Soil Cone Penetrometer. Standars engineering practices data (pp. 903-904). St. Joseph: ASABE. 
Bai, J., \& Ng, S. (2005). Tests for skewness, kurtosis, and normality for time series data. Journal of Business \& Economic Statistics, 23, 49-60. http:// dx.doi.10.1198/073500104000000271.

Bai, J. (2003). Testing parametric conditional distributions of dynamic models. The Review of Economics and Statistics, 85, 531-549.

Baio, F. H. R. (2012). Evaluation of an auto-guidance system operating on a sugarcane harvester. Precision Agriculture, 13, 141-147. http:// 10.1007/s11119-011-9241-6.

Batte, M. T., \& Ehsani, M. R. (2006). The economics of precision guidance with auto-boom control for farmer-owned agricultural sprayers. Computer Electronic in Agriculture, 53, 28-44. http://dx.doi.org/10.1016/j.compag.2006.03.004

Buol S. W., Southard, R. J., Graham, R. C., \& McDaniel, P. A. (2011). Morphology and composition soil. In S. W. Buol, R. J. Southard, R. C. Graham, \& P. A. McDaniel (Eds.), Soil genesis and classification (pp. 33-75). Danvers: Wiley-Blackwell.

Garside, A. L., Bell, M. J., \& Robotham, B. G. (2009a). Row spacing and planting density effects on the growth and yield of sugarcane. 2. Strategies for the adoption of controlled traffic. Crop and Pasture Science, 60, 544-554. http://dx.doi.org/10.1071/CP08312

Garside, A. L., \& Bell, M. J. (2009b) Row spacing and planting density effects on the growth and yield of sugarcane. 3. Responses with different cultivars. Crop and Pasture Science, 60, 555-565. http://dx.doi.org/10.1071/CP08313

Gil-Sierra, J., Ortiz-Cañavate, J., Gil-Quirós, V., \& Casanova, J. K. (2007). Energy efficiency in agricultural tractors: a methodology for their classification. Applied Engineering Agriculture, 23, 145-150.

Grisso, R. D., Kocher, M. F., \& Vaughan, D. H. (2004). Predicting tractor fuel consumption. Applied Engineering in Agriculture, 20, 553-561.

Håkansson, I. (2005). Effects of compaction on crop growth and yield. In I. Håkansson (Ed.), Machinery-induced compaction of arable soils: incidence, consequences, counter-measures (pp. 61-85). Uppsala: Swedish University of Agricultural Sciences.

Heraud, J. A., \& Lange, A. F. (2009). Automatic vehicle guidance from horses to GPS: how we got here, and where we are going (Publication number 913C0109). Paper presented at the Agricultural Equipment Technology Conference, Louisville, Kentucky, 9-12 February 2009. http://elibrary.asabe.org.

Ivancan, S., Sito, S., \& Fabijanic, G. (2004). Effect of precision on the intra-row seed distribution for parsley drill operating speed. Biosystems Engineering, 89, 373-376. http://doi:10.1016/j.biosystemseng.2004.07.007

Karra, P., \& Fernando, S. (2005). Soybean oil based four-stroke engine crankcase lubricants (Paper Number: 056122). Paper presented at the ASAE Annual International Meeting, Tampa Convention Center, Florida, Retrieved 17-20 July, 2005, from http://elibrary.asabe.org

Kichler, C. M., Fulton, J. P., Raper, R. L., Zech, W. C., McDonad, T. P., \& Brodbeck, C. J. (2007). Spatially monitoring tractor performance to evaluate energy requirements of variable depth tillage and implement selection (Paper Number: 071028). Paper presented at the Paper presented at the ASABE Annual International Meeting, Minneapolis Conventional Center, Minnesota, Retrieved 17-20 June, 2007, from http://elibrary.asabe.org.

Kim, T. H., \& White, H. (2004). On more robust of skewness and kurtosis. Finance Reserch Letters, 1, 56-73.

Kumar, S., \& Singh, B. R. (2012). Performance feasibility and economic viability of sugarcane planter in western Plane zone of Uttar Pradesh, India. Sugar Tech, 14, 101-108. http:// dx.doi.org/10.1007/s12355-012-0134-4

John Deere. (2008). Tractors de 180 e 200 hp. Technical Manual. Retrieved from http://www.deere.com/pt_BR/ag/products/new-equipment/pdf/tr7x15_pt.pdf

Jones, J. B. (2001). Soils Analysis. In J B Jones (Ed.), Laboratory guide for conducting soil tests and plants analysis (pp. 11-160). Boca raton: CRC Press.

Léon, A., Rubio, G., \& Serna, G. (2005). Autoregresive conditional volatility skewness and kurtosis. The Quarterly Review of Economics and Finance, 45, 599-618.

Liljedahl, J. B., Turnquist, P. K., Smith, D. W., \& Hoki, M. (1989). Tractor tests and performance. In J. B. Liljedahl, P. K. Turnquist, D. W. Smith, \& M. Hoki (Eds.), Tractors and their power units (pp. 403-438), New York: Van Nostrand Reinhold. 
Mudholkar, G. S., \& Natarajan, R. (2002). The inverse Gaussian models: analogues of symmetry, skewness and kurtosis. Annals of the Institute of Statistical Mathematics, 54,138-154.

Pripps, R. N. (2004). Air, water, oil cooling and systems. In R. N. Pripps (Ed.), Farm tractor (pp. 60-77). Minnesota: MBI Publishing Company.

Rípoli, M. L. C., Rípoli, T. C. C., Casagrandi, D. V., \& Ide, B. Y. (2007) Evaluation of five sugar cane planters (Paper Number: 071077). Paper presented at the ASABE Annual International Meeting, Minneapolis Conventional Center, Minnesota, 17-20 June 2007. Retired from http://elibrary.asabe.org.

Rípoli, M. L. C., \& Rípoli, T. C. C. (2010). Evaluation of five sugar cane planters. Engenharia Agrícola, 30, 1110-1122. http://dx.doi.org/10.1590/S0100-69162010000600012

Shockley, J. M., Dillon, C. R., \& Stombaugh, T. S. (2011). A whole farm analysis of the influence of auto-steer navigation on net returns, risk, and production practices. Journal of Agricultural and Applied Economics, 43, 57-75.

Srivastava, A. K., Goering, C. E., Rohrbach, R. P., \& Buckmaster, D. R. (1993). Tractor hitching, traction, and testing. In A. K. Srivastava, C. E. Goering, R. P. Rohrbach, \& D. R. Buckmaster (Eds.), Engineering principles of agricultural machines (pp. 139-167). St. Joseph: ASAE.

TMA - Tracan Máquinas Agrícolas. (2013). Planter PTX 7010. Technical Manual. Retrieved from www.tmamaquinas.com.br/plantadora_ptx_7010.php.

Vishwanathan, O., Weckler, P. R., Solie, J. B., \& Stone, M. S. (2005). Evaluation of ground speed sensing devices under varying ground surface conditions (Paper Number: 051087). Paper presented at the ASAE Annual International Meeting, Tampa Convention Center, Florida, 17-20 July. Retired from http://elibrary.asabe.org.

Yadav, R. N. S., Yadav, S., \& Terja, R. K. (2003). Labour saving and cost reduction machinery for sugarcane cultivation. Sugar Tech., 5, 7-10.

Yadav, R. N. S., Chaudhuri, D., Sharma, M. P., Singh, P. R., Kamthe, S. D., \& Tajuddin, A. (2004). Evaluation, refinement and development of tractor operated sugarcane cutter planters. Sugar Tech, 6, 5-14.

\section{Copyrights}

Copyright for this article is retained by the author(s), with first publication rights granted to the journal.

This is an open-access article distributed under the terms and conditions of the Creative Commons Attribution license (http://creativecommons.org/licenses/by/3.0/). 